\title{
PRZESŁANKI WDRAŻANIA CYFRYZACJI JEDNOSTEK SAMORZĄDU LOKALNEGO FINANSOWANEJ ZE ŚRODKÓW UNIJNYCH
}

\section{WPROWADZENIE}

Nowy wymiar kontaktów z klientami bądź pobudzanie innowacyjności pracowników administracji stanowią dwie spośród wielu korzyści leżących u podstaw wspierania idei cyfryzacji w różnych sektorach gospodarczych. Dla wielu przedsiębiorstw transformacja cyfrowa stała się jednym z głównych celów strategicznych, a jej wpływ na funkcjonowanie podmiotów na dynamicznie zmieniającym się rynku jest oczywisty. W przypadku sektora finansów publicznych zwiększenie poziomu digitalizacji w dużej mierze stało się możliwe dzięki środkom unijnym, które są narzędziami prowadzonej przez Unię Europejską od lat polityki spójności ${ }^{1}$. Przesłanki decydujace o przeprowadzeniu cyfryzacji urzędów stanowią stosunkowo słabo zbadany obszar, co wynika w dużej mierze z faktu, że cyfryzacja podsektora samorządowego jest procesem ciagłym, którego początek związany jest z perspektywą finansowa 2007-2013. Celem niniejszego artykułu jest zatem zidentyfikowanie czynników wpływających na decyzje samorządu o inwestowaniu środków unijnych w cyfryzację, oparte na badaniu empirycznym mającym charakter badania pilotażowego przeprowadzonego na podstawie wywiadów telefonicznych z osobami zatrudnionymi w wybranych urzędach. Artykuł składa się z trzech części. W pierwszej - teoretycznej przedstawiono m.in. zagadnienia e-administracji, administracji elektronicznej, elektroniczne usługi publiczne w kontekście Unii Europejskiej i Polski, „Program Polska Cyfrowa 2014-2020” - plan finansowy. W części drugiej - empirycznej zaprezentowano wyniki badania umożliwiającego weryfikację wyłonionych czynników. Artykuł zamykają wnioski oraz perspektywy dalszego przebiegu cyfryzacji w sektorze publicznym oraz wzrostu jej znaczenia.

${ }^{1}$ Sikora-Gaca, Piechowicz, Kleinowski (2018): 17-61. 


\section{KONCEPCJA NEW PUBLIC MANAGEMENT PODSTAWĄ TEORETYCZNĄ CYFRYZACJI}

Idealna organizacja, która została nazwana przez Webera² biurokracja, była strukturą przewidywalną i takie też miały być efekty jej działalności. Kluczową rolę w modelu zaproponowanym przez badacza miały kompetencje osób na poszczególnych stanowiskach, od których zależała kariera i awanse pracowników. Podstawowe założenia modelu definiują:

- hierarchia i jasno określony łańcuch służbowy,

- legalna władza jako pewnik gwarantujący ciagłość organizacyjną na wszystkich stanowiskach,

- dokumentowanie wszystkich działań i procesów,

- wyłączność zatrudnienia wszystkich pracowników (organizacja jest ich jedynym lub głównym miejscem pracy).

Koncepcja Webera przyczyniła się do powstania metafory organizacji jako maszyny ${ }^{3}$. Lawinowy wzrost dokumentacji, monotonia pracy, a także dystansowanie się pracowników wobec organizacji to tylko niektóre z wad przedstawionego modelu. Odpowiedzią na krytykę biurokracji było powstanie nowych rozwiązań, m.in. New Public Management (NPM), który można zdefiniować jako „model administrowania publicznego bazujący na zarządzaniu”. Inne określenia tego modelu wprowadzone w literaturze przedmiotu to menedżeryzm $^{5}$, rynkowa administracja publiczna ${ }^{6}$ czy zarządzanie na zasadach biznesowych ${ }^{7}$. Zawicki ${ }^{8}$ wskazuje na następujące elementy New Public Management:

- orientacja na osiaganie wyników;

- przejście od administracji tradycyjnej do modelu przesuwającego odpowiedzialność na kierowników;

- wprowadzenie elastycznych warunków zatrudnienia, pracy i organizacji;

- jasną definicję celów, których zakres realizacji jest mierzalny za pomoca wskaźników: oszczędność, efektywność i skuteczność;

- niektóre z zadań realizowanych przez sektor publiczny są poddawane ocenie na rynku w postaci kontraktów.

Nowy system zarządzania oznacza przede wszystkim tworzenie administracji przyjaznej obywatelowi. O sprawności New Public Management decydują skuteczność i efektywność działania systemu. Przy czym skuteczność odnosi się do stopnia realizacji założonych celów, z kolei efektywność definiuje stopień osiagnięcia celu przy minimalnych kosztach lub maksymalizację

\footnotetext{
${ }^{2}$ Weber (2004).

${ }^{3}$ Morgan (1999): 17-40.

${ }^{4}$ Zawicki (2002): 78.

5 Pollitt (1990).

${ }^{6}$ Lan, Rosenbloom (1992): 535-537.

7 Kickert (1990): 731-752.

8 Zawicki (2002): 78-79.
} 
stopnia osiagnięcia celu przy założonych kosztach ${ }^{9}$. Zatem należy podkreślić, że New Public Management jest nie tylko nowym sposobem zarządzania administracja publiczna, lecz także nowym wymiarem udostępnienia obywatelom usług, przy relatywnie niskim obciążaniu budżetu państwa kosztem ich świadczenia. Skuteczność w modelu nie jest uzależniona od dostępnych środków finansowych ani pojedynczych wydatków budżetu jednostek samorządowych, ale tego, co udało się dzięki tym wydatkom osiagnąc - istotny okazuje się efekt $\mathrm{t}^{10}$. Wprowadzenie założeń New Public Management jest możliwe dzięki zastosowaniu nowych koncepcji zarządzania, takich jak:

- Lean management, czyli uproszczenia organizacji i zarządzania. W dużej mierze koncepcja ta realizowana jest przy współpracy publicznych instytucji z sektorem prywatnym, co określa się jako partnerstwo publiczno-prywatne $\mathrm{e}^{11}$;

- Reengineering, czyli rezygnacja $\mathrm{z}$ tradycyjnych struktur opartych na podziale zadań na rzecz struktur procesowych. Celem koncepcji jest rekonstrukcja procesów przez: skrócenie czasu ich przebiegu, zmniejszenie kosztów i poprawę jakości ${ }^{12}$;

- organizacja inteligentna, czyli taka, która kieruje się zasadami logiki, działa zgodnie z prawem, aby wzbogacić wartości leżące u podstaw jej kreacji i funkcjonowania, w takiej organizacji najważniejsze są wartości niematerialne, w tym w szczególności wiedza ${ }^{13}$.

Koncepcja NPM przekłada się na sprawne i efektywne funkcjonowanie administracji, jednocześnie współdziałając z założeniami Good Governance (będącego narzędziem dobrych praktyk $\mathrm{w}$ zarządzaniu) ${ }^{14}$, co przedstawia poniższy wykres.

\section{Schemat 1}

Od zarządzania tradycyjnego do Good Governance

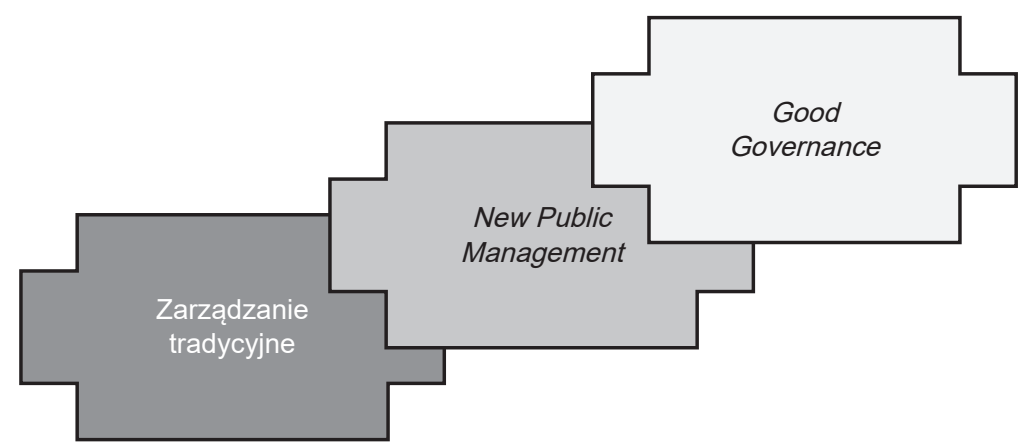

Źródło: opracowanie własne.

\footnotetext{
9 Lubińska et al. (2007): 56.

10 Ochnio (2012).

11 Jeżowski (2002): 17.

12 Krynicka (2006): 200.

13 Boć (2003): 366-374.

14 Ministerstwo Rozwoju Regionalnego (2008); Prokopowicz, Kwasek (2017): 176-188.
} 
Warto podkreślić, że „good governance można identyfikować w działaniach całej administracji publicznej. Powinno to skłaniać aparat państwowy do zaangażowania na rzecz urzeczywistniania dobrego rządzenia, jako narzędzia gwarantującego osiaganie jak najlepszych efektów podejmowanych działań"15.

Nie bez znaczenia są także głosy przeciwników New Public Management wskazujące na ograniczone możliwości zastosowania modelu do potrzeb sektora publicznego, m.in. fakt, że rynki tworzone w sektorze publicznym nie sa rynkami wolnej konkurencji, lecz rynkami konkurencji organizowanej przez władze publiczne, lub że siły rynkowe nie wystarczą do osiagnięcia zadowolenia konsumentów ${ }^{16}$.

Podsumowując, Sześciło i Bełdowski ${ }^{17}$ wskazuja, że: „model biurokratyczny był właściwy $\mathrm{w}$ warunkach gospodarek przemysłowych pierwszej połowy XX wieku. Doszedł jednak do kresu i nie odpowiada już wymogom czasów, których symbolem jest rozwój technologii komunikacyjnych i rozwój gospodarki opartej na wymianie informacji, a nie na produkcji przemysłowej”. Realizacji wspomnianych przez naukowców celów (technologii komunikacyjnych i rozwoju gospodarki opartej na wymianie informacji, a także podstawowego założenia jawności i przejrzystości finansów publicznych ${ }^{18}$ ) służy niewątpliwie rozwijanie sieci teleinformatycznych i cyfryzacja usług oferowanych przez samorządy lokalne.

\section{PODSTAWOWE POJĘCIA DOTYCZĄCE CYFRYZACJI}

Cyfryzacja jest procesem złożonym i może być definiowana jako adaptacja i wzrost wykorzystywania technologii cyfrowych lub komputerowych przez organizacje, sektory gospodarki, kraje ${ }^{19}$. Cyfryzacja jest jednak pojęciem bardzo szerokim obejmującym różne zagadnienia, dlatego w celu doprecyzowania pojęcia cyfryzacji w kontekście działania samorządów lokalnych zdefiniowane zostaną pojęcia, które będą stosowane w dalszej części artykułu: e-administracja, administracja elektroniczna, elektroniczne usługi publiczne.

E-administracja jest terminem, który na stałe znalazł zastosowanie w terminologii specjalistycznej. W literaturze obcojęzycznej pojawia się e-Government ${ }^{20}$, który definiowany jest w różny sposób, niemniej aby uniknaćc przytaczania wielu definicji, możliwy jest podział na wąską i szeroką koncepcję pojmowania zjawiska $^{21}$. Stany Zjednoczone oraz państwa azjatyckie (Japonia, Korea) koncentrują się na kwestii zapewnienia dostępu do usług publicznych świadczonych drogą elektroniczną ${ }^{22}$. Z kolei OECD czy UE definiują e-Government jako okazję

\footnotetext{
15 Ministerstwo Rozwoju Regionalnego (2008).

${ }^{16}$ Krynicka (2006): 202.

17 Sześciło, Bełdowski (2018).

18 Ustawa z 27 sierpnia 2009 r. o finansach publicznych, Dz. U. 2009, Nr 157, poz. 1240 ze zm.

19 Gajewski (2016).

${ }^{20}$ M.in. Weerakkody et al. (2012).

21 Grodzka (2009): 57-81.

22 Ganczar (2009).
} 
„do wypracowania nowych stosunków między instytucjami sektora publicznego, obywatelami i przedsiębiorstwami przez wykorzystanie ICT [technologii informacyjno-komunikacyjnych - K.D.] $]^{23}$, które umożliwiają rozpowszechnianie i gromadzenie informacji i usług wewnattrz sektora publicznego i w celu świadczenia usług, podejmowania decyzji i wzrostu odpowiedzialności" ${ }^{24}$. E-Government w takim ujęciu oznacza pojęcie zdecydowanie szersze, gdyż poza udostępnieniem usług świadczonych drogą elektroniczna, obejmuje także modernizację całego systemu administracji, bazującego na fundamencie ICT, w celu ułatwienia dostępu do usług obywatelom państwa ${ }^{25}$. W polskiej literaturze przedmiotu termin e-Government zastępowany jest przez pojęcie „elektroniczna administracja”. Oba pojęcia sa stosowane zamiennie, choć jest to dużym uproszczeniem ${ }^{26}$. Szyszka i Śliwczyński proponują definicję e-administracji obejmująca zelektronizowane relacje informacyjno-komunikacyjne zewnętrzne: urząd-obywatel, urząd-przedsiębiorca, urząd-usługodawca oraz wewnętrzne: urząd-urząd, urząd-pracownicy ${ }^{27}$. W przytoczonym sformułowaniu bardzo wyraźnie można zauważyć punkt ciężkości położony na relację urzędu z otoczeniem.

Podsumowujacc, e-administracja ma być elastycznym, otwartym mechanizmem zapewniającym współpracę pracowników na różnych szczeblach w celu załatwienia indywidualnych spraw interesantów ( $\mathrm{w}$ tym obywateli i przedsiębiorców, osób fizycznych i prawnych) oraz zaspokajania ich zbiorowych potrzeb ${ }^{28}$.

Sakowicz ${ }^{29}$ rozróżnia takie, pojęcia jak: e-usługi (e-services), e-administracja (e-management), e-demokracja (e-democracy) oraz e-handel (e-commerce), które mieszczą się w obrębie koncepcji e-Government, co wskazuje na złożony i jednocześnie dynamiczny charakter procesu. Jednym z jasnych przejawów zmian dokonujacych w ramach koncepcji e-government, a dokładniej: e-administracji - jest rozwój elektronicznych usług publicznych, wykazujący znaczne zróżnicowania przestrzenne ${ }^{30}$.

Na potrzeby niniejszego artykułu przyjęto za Śliwińskim ${ }^{31}$ następujące cechy definiujace usługi elektroniczne (e-usługi) ${ }^{32}$ :

- są świadczone w sposób częściowo lub całkowicie zautomatyzowany przez technologię informacyjna,

- sa realizowane w Internecie i za pośrednictwem Internetu,

- sa zindywidualizowane względem odbiorcy (personalizowane),

- strony świadczonej usługi znajdują się w różnych miejscach (usługa zdalna).

${ }^{23}$ Ang. ICT - Information and Communication Technologies.

${ }^{24}$ Definicja ze strony internetowej OECD Directorate for Public Governance and Territorial Development, <http://www.oecd.org/document/29/0,3746,en_2649_34129_1830941_1_1_1_1,00.html> [dostęp: 16.12.2018].

${ }^{25}$ Bogucki (2005).

${ }^{26}$ Porębski (2012).

${ }^{27}$ Szyszka, Śliwczyński (2004): 86.

${ }^{28}$ Fleszer (2014): 125-136.

${ }^{29}$ Sakowicz (2007).

${ }^{30}$ Centeno, van Bavel, Burgelman (2005): 59-66.

31 Śliwiński (2008).

${ }^{32}$ Na potrzeby niniejszego artykułu termin cyfryzacja jest utożsamiany z terminem e-usługi. 
Batko i Billewicz ${ }^{33}$ podają następujący przykład rozwoju e-usług na poziomie e-administracji:

Tabela 1

Rodzaje i przykłady e-usług w podziale na obszary wykorzystania

\begin{tabular}{|c|c|c|}
\hline Obszar & Rodzaj e-usługi & Przykład \\
\hline \multirow{3}{*}{ e-administracja } & ogólnokrajowe platformy e-administracji & epuap.pl \\
\hline & regionalne platformy e-administracji & sekap.pl \\
\hline & $\begin{array}{l}\text { portale umożliwiające przesyłanie dokumentów } \\
\text { np. rozliczeń podatkowych }\end{array}$ & e-deklaracje.gov.pl \\
\hline
\end{tabular}

Źródło: Batko, Billewicz (2013): 52.

Zależność między zaprezentowanymi w artykule pojęciami można przedstawić graficznie, jak na poniższym schemacie.

\section{Schemat 2}

Zależność między cyfryzacja, e-administracją i e-usługami

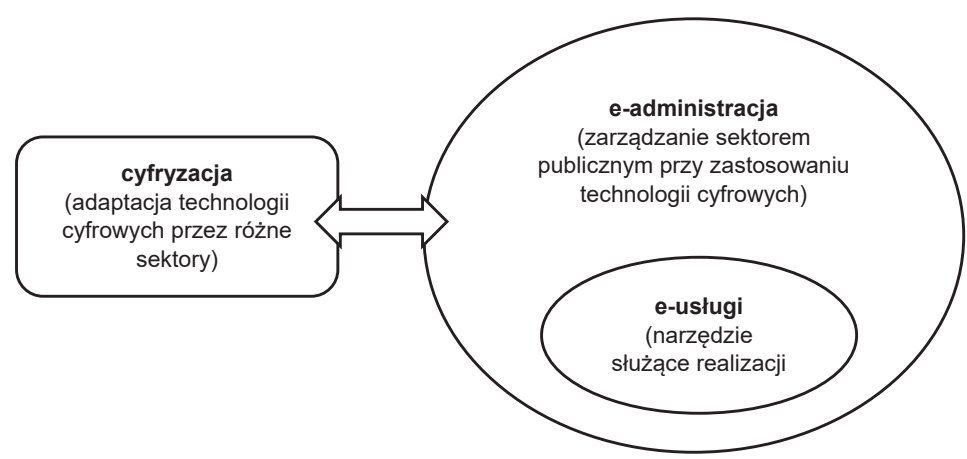

Źródło: opracowanie własne.

\section{PODSTAWY PRAWNO-GOSPODARCZE CYFRYZACJI ADMINISTRACJI SAMORZĄDOWEJ}

Przystapienie Polski do UE w 2004 r. wymogło dostosowanie prawa polskiego do wymogów europejskich. Jednakże w dziedzinie e-administracji tego typu normy należą do rzadkości, co wynika z podziału kompetencji zapisanych

${ }^{33}$ Batko, Billewicz (2013): 47-63. 
w Traktacie o funkcjonowaniu Unii Europejskiej - zmodyfikowanym przez Traktat z Lizbony (2007), w którym przyjęto, że zagadnienia związane z „przestrzenią wolności, bezpieczeństwem i sprawiedliwością" należą do kompetencji dzielonych UE i państw członkowskich (art. 4 TFUE), a kwestie związane ze współpracą administracyjną w wymiarze europejskim należą do kompetencji wspierających UE (art. 6 TFUE) ${ }^{34}$. Jednym z ważniejszych aktów unijnych, wpływających na sytuację prawną e-administracji w Polsce, była dyrektywa 2003/98/WE Parlamentu Europejskiego i Rady z 17 listopada 2003 r. w sprawie ponownego wykorzystywania informacji sektora publicznego. Dyrektywa regulowała kwestie związane z dostępem do informacji publicznej i wpłynęła na zapisy ustawy o dostępie do informacji publicznej oraz wykorzystywaniu danych zgromadzonych przez sektor publiczny. Zapis tej ustawy przełożył się na sposób gromadzenia i przetwarzania danych w wielu centralnych projektach informatycznych ${ }^{35}$.

Zasadniczo można wymienić następujące ustawy, które w istotny sposób wpłynęły na kształtowanie e-administracji w jednostkach samorządu lokalnego:

- ustawa z 6 września 2001 r. o dostępie do informacji publicznej, wprowadzająca Biuletyn Informacji Publicznej (Dz. U. Nr 112, poz. 1198),

- ustawa z 18 września 2001 r. o podpisie elektronicznym (Dz. U. Nr 130, poz. 1450),

- ustawa z 17 lutego 2005 r. o informatyzacji działalności podmiotów realizujących zadania publiczne (Dz. U. Nr 64, poz. 565) ${ }^{36}$.

Pierwszym aktem prawnym, w którym znalazły się przepisy wprowadzające ideę e-administracji do polskiego porządku prawnego, była ustawa z 6 września 2001 r. o dostępie do informacji publicznej, w której wprowadzono obowiąek wydawania, w formie publikatora teleinformatycznego, „Biuletynu Informacji Publicznej" 37 . Ustawa o świadczeniu usług drogą elektroniczna była częścią pakietu ustaw regulujących handel, odbywający się przy wykorzystaniu systemów teleinformatycznych. Uchwalenie tych regulacji miało na celu dostosowanie polskiego prawa do wymogów wynikajacych $\mathrm{z}$ dyrektyw unijnych, w szczególności dyrektywy z 8 czerwca 2000 r. w sprawie niektórych aspektów prawnych usług w społeczeństwie informacyjnym, w szczególności handlu elektronicznego (dyrektywa nr 2000/31) ${ }^{38}$. Ustawa z 18 września 2001 r. o podpisie elektronicznym była pierwszym dokumentem, w którym zawarte zostały regulacje dotyczące stosowania na szerszą skalę komunikacji elektronicznej w sprawach urzędowych. Natomiast ramy funkcjonowania e-administracji w Polsce wyznaczyła ustawa z 17 lutego 2005 r. o informatyzacji działalności podmiotów realizujących zadania publiczne. Jej przepisy określają m.in. zasady ustalania minimalnych, gwarantujaccych otwartość stan-

\footnotetext{
34 Perdał (2014): 45.

35 Perdał (2014): 45.

36 Butkiewicz (2006).

37 Dane ze wszystkich instytucji i samorządów z całej Polski zebrane są na: www.bip.gov.pl.

38 Zob. <https://e-prawnik.pl/artykuly/zakres-ustawy-o-swiadczeniu-uslug-droga-elektroniczna. html> [dostęp: 16.12.2018].
} 
dardów informatycznych, wymagań dla systemów teleinformatycznych oraz rejestrów publicznych i wymiany informacji w formie elektronicznej z podmiotami publicznymi ${ }^{39}$.

\section{PROGRAM OPERACYJNY POLSKA CYFROWA 2014-2020}

Od 2004 r., kiedy Polska stała się członkiem Unii Europejskiej, realizowane są konkretne polityki horyzontalne, wynikajace z poszczególnych perspektyw finansowych ${ }^{40}$. Nowa perspektywa finansowa obowiązujacca w latach 2014-2020 zastapiła perspektywę z lat 2007-2013, a w nowym budżecie europejskim przyznano Polsce rekordowe 82,5 mld euro. Beneficjentami tych środków, podobnie jak w poprzedniej perspektywie, są jednostki samorządu terytorialnego (JST).

„Celem programu [Polska Cyfrowa 2014-2020 - K.D.] jest wzmocnienie cyfrowych fundamentów dla rozwoju kraju. Zgodnie z Umową Partnerstwa (UP), jako fundamenty te przyjęto: szeroki dostęp do szybkiego Internetu, efektywne i przyjazne użytkownikom e-usługi publiczne oraz stale rosnacy poziom kompetencji cyfrowych społeczeństwa" ${ }^{41}$.

Program obejmuje cztery osie priorytetowe:

I. Powszechny dostęp do szybkiego Internetu.

II. E-administracja i otwarty rząd.

III. Cyfrowe kompetencje społeczeństwa.

IV. Pomoc techniczna.

Dla rozważań w niniejszym artykule istotne są główne założenia (cele szczegółowe) II osi priorytetowej: E-administracja i otwarty rząd, a także beneficjenci tej części programu, koszty jej realizacji i składające się na nią zadania. Zatem - jak wskazano w programie - cele szczegółowe osi II to:

1) Wysoka dostępność i jakość e-usług publicznych

- Beneficjenci: jednostki administracji rządowej, podmioty podległe jednostkom administracji rządowej lub przez nie nadzorowane.

- Nakłady finansowe: 689804018 EUR.

- Zadania:

- tworzenie lub rozwój e-usług publicznych,

- tworzenie lub rozwój usług wewnątrzadministracyjnych niezbędnych dla funkcjonowania e-usług publicznych.

2) Cyfryzacja procesów wspierających podstawową działalność administracji rządowej

- Beneficjenci: jednostki administracji rządowej, podmioty podległe jednostkom administracji rządowej lub przez nie nadzorowane, partnerstwa tworzone pomiędzy wskazanymi powyżej wnioskodawcami.

\footnotetext{
39 Grodzka (2007).

40 Sikora-Gaca, Kosowska (2014).

${ }^{41}$ Program Operacyjny Polska Cyfrowa na lata 2014-2020: 3.
} 
- Nakłady finansowe: 55000000 EUR.

- Zadania:

- przenoszenie gotowych rozwiązań IT między urzędami, w tym opracowanie i wdrożenie horyzontalnych rozwiązań możliwych do zastosowania w skali całej administracji,

- działania edukacyjne i szkoleniowe, niezbędne do zapewnienia funkcjonowania rozwiązań IT wspieranych w ramach typów 1 i 2.

3) Cyfrowa dostępność i użyteczność informacji sektora publicznego

- Beneficjenci: centralne jednostki administracji rządowej oraz jednostki im podległe, ogólnokrajowi nadawcy radiowi i telewizyjni, jednostki naukowe.

- Nakłady finansowe: 93368019 EUR.

- Zadania:

- cyfrowe udostępnienie informacji sektora publicznego ze źródeł administracyjnych,

- cyfrowe udostępnienie zasobów nauki.

4) Tworzenie usług i aplikacji wykorzystujacych e-usługi publiczne i informacje sektora publicznego:

- Beneficjenci: jednostki naukowe, organizacje pozarządowe, przedsiębiorcy.

- Nakłady finansowe: 101431981 EUR.

- Zadania:

- wdrożenie nowej usługi świadczonej przez aplikację elektroniczna lub rozszerzenie funkcjonalności już istniejącej e-usługi (aplikacji) poprzez wykorzystanie treści otwartych zasobów informacji sektora publicznego i/lub istniejaccych usług publicznych ${ }^{42}$.

Przedstawione powyżej dane wskazują najistotniejsze zadania i cele Programu Polska Cyfrowa oraz podstawowych beneficjentów programu.

\section{CZYNNIKI WPEYWAJĄCE NA POZYSKIWANIE ŚRODKÓW NA ROZWÓJ ADMINISTRACJI ELEKTRONICZNEJ W SAMORZĄDACH LOKALNYCH}

Perdał ${ }^{43}$ wyróżnia następujące czynniki wpływające na zwiększenie usług świadczonych za pomoca technologii teleinformatycznych w sektorze publicznym. Zaprezentowane czynniki stanowią punkt wyjścia rozważań dotyczących ich wpływu na potencjalne decyzje dotyczące ubiegania się o finansowanie wprowadzenia bądź rozwoju cyfryzacji ze środków unijnych, a następnie zostaną zweryfikowane na podstawie rozmów z pracownikami wybranych urzędów.

Do zewnętrznych, zlokalizowanych „poza urzędami” zaliczyć można: (1) poziom rozwoju społeczno-gospodarczego warunkowany globalizacją i rozwojem

42 Program Operacyjny Polska Cyfrowa na lata 2014-2020: 22-33.

${ }^{43}$ Perdał (2014): 146-147. 
społeczeństwa informacyjnego; (2) postawy, wiedzę i umiejętności obywateli; (3) wielkość jednostki administracyjnej wyrażonej w liczbie zamieszkujących obywateli; (5) oczekiwania obywateli.

Natomiast czynniki o charakterze wewnętrznym, rozumiane jako skład i otoczenie wewnętrzne systemu e-administracji, to: (1) sytuacja finansowa gminy i wyposażenie teleinformatyczne oraz (2) współpraca i partnerstwo (3) postawa liderów i władz.

\section{Czynniki zewnętrzne}

Poziom rozwoju społeczno-gospodarczego traktuje się jako synergiczny efekt działania procesów rozwojowych w warunkach globalizacji i rozwoju społeczeństwa informacyjnego $\mathrm{w}$ terytorialnych systemach społecznych (w tym przypadku szczebla lokalnego) ${ }^{44}$. Wynika z tego prosta zależność, że im wyższy poziom społeczno-gospodarczy gmin, tym lepsza sytuacja finansowa mieszkańców i urzędów administracji publicznej. Perdał w swoich badaniach przeanalizował sytuację aglomeracji poznańskiej, zauważając jej silną pozycję rozwojową na tle kraju, co jednocześnie wpływa na intensyfikację działań cyfryzacyjnych ${ }^{45}$. Wyższy poziom rozwoju gospodarczego gmin przekłada się na tempo i jakość działań rozwojowych i jednocześnie jest punktem wyjścia budowy nowych systemów, m.in. dotyczących cyfryzacji. W dużym stopniu sytuacja rozwojowa gminy umożliwia większy zakres działań, przez co wpływa na pozostałe czynniki zewnętrzne, takie jak: dostęp do struktury teleinformatycznej, postawę władz, czy wiedzę i umiejętności obywateli.

Tomaszewicz i Buko ${ }^{46}$ zauważaja, że technologie informacyjno-komunikacyjne sa niezbędne $\mathrm{w}$ procesie budowy e-administracji, $\mathrm{w}$ tym $\mathrm{w}$ rozwoju treści i systemu e-usług. Niejednokrotnie rozwój technologii idzie w parze z wspomnianą już wcześniej silną pozycją rozwojową. Jedną z podstawowych przesłanek umożliwiających rozwój e-administracji jest dostęp obywateli do Internetu, który wprawdzie z roku na rok się poprawia (w Polsce z $34 \%$ w roku 2007 do $82 \%$ w $2018^{47}$ ), jednakże ciagle istnieje znaczna dysproporcja między obszarami miejskimi i wiejskim w tym zakresie. Rozwój w tym obszarze powoduje coraz to lepsze możliwości komunikacji na odległość i jednocześnie doprowadza do wzajemnego przenikania się technologii i usług, które przez długi czas zazwyczaj traktowano odrębnie ${ }^{48}$. Także Wilk ${ }^{49}$ zauważa, że „w opinii przedstawicieli jednostek administracji publicznej barierą ograniczająca rozwój elektronicznej administracji jest słaba dostępność do Internetu [...]. Przedstawiciele jednostek administracji publicznej zwracali uwage na problemy związane z dostępnością do Internetu, szczególnie na obszarach wiej-

44 Perdał (2014): 147.

45 Perdał (2014): 147.

46 Tomaszewicz, Buko (2015): 644.

${ }^{47}$ Eurostat, <http://ec.europa.eu/eurostat/product?code=isoc_ci_in_h\&language=en\&mode=view> [dostęp: 20.12.2018].

${ }^{48}$ Kancelaria Prezesa Rady Ministrów (2009): 146.

49 Wilk (2014): 133. 
skich”. Jednocześnie przytoczone już wcześniej badanie Perdała ${ }^{50}$ potwierdza, że na liczbę usług, z których można skorzystać elektronicznie, a zatem także na staranie się o wpływy na cyfryzację, ma przede wszystkim chęć i potrzeba szybkiego załatwienia spraw urzędowych, obycie z rozwiązaniami teleinformatycznymi, które cechuje w dużej mierze osoby młodsze ${ }^{51}$, czynne zawodowo; ważną rolę odgrywa także poziom wiedzy i świadomości dotyczący nowych rozwiązań, a cechy te sa charakterystyczne dla większych aglomeracji miejskich. Mieszkańcy większych aglomeracji będą zatem oczekiwali od urzędów e-usług, co przełoży się na intensyfikację działań w celu pozyskania środków unijnych.

W większości przypadków posiadanie komputera i telefonu komórkowego z dostępem do Internetu, a zatem potencjalna możliwość korzystania z usług oferowanych $\mathrm{w}$ ramach e-administracji, uwarunkowana jest wiekiem, wykształceniem i statusem społeczno-zawodowym. Mieszkańcy większych aglomeracji będą zatem oczekiwali od urzędów e-usług, co przełoży się na intensyfikację działań w celu pozyskania środków unijnych.

\section{Czynniki wewnętrzne}

Niewątpliwie najczęściej wspominaną przez autorów przesłanką dotyczącą pozyskania środków na cyfryzację urzędów jest sytuacja finansowa gminy ${ }^{52}$. Najlepsza sytuacja finansowa występuje w gminach o najwyższym dochodzie na mieszkańca, co także wskazuje na wyższe wydatki na inwestycje i stanowi potencjalne źródło finansowania e-administracji ${ }^{53}$. Sytuacja finansowa gminy przekłada się nie tylko na inwestycje sprzętowe oraz systemowe w zakresie cyfryzacji, np. systemy powiadamiania przed zagrożeniami, ale także na możliwość zlecania przygotowywania wniosków o dotacje unijne firmom zewnętrznym lub tworzenie odrębnych stanowisk, co zwiększa szanse na pozyskanie dotacji. Gminy, z zasady większe, dysponujące większymi funduszami maja możliwość zaproponowania większego wkładu własnego, zatem mogą się tym samym ubiegać o większe dofinansowanie unijne.

Czubak $^{54}$, analizując pozyskiwanie środków unijnych w rolnictwie, zauważa, że „głównymi przyczynami, dla których rolnicy decydowali się na udział w programie, były potrzeby inwestycyjne w gospodarstwie". Potrzeby w zakresie możliwości sprzętowych urzędu zdają się także należeć do czynników motywujących do pozyskiwania dotacji unijnych na cyfryzację. Tym bardziej że wprowadzenie funkcjonujacej e-administracji wymaga przede wszystkim dostosowania rozwiązań sprzętowych do nowych warunków działania w ramach e-usług. Dodatkowo ogromne znaczenie przy pozyskiwaniu funduszy unijnych na cyfryzację ma fakt współpracy i tworzenia związków gmin lub ścisłej współpracy z podmiotami zewnętrznymi, które wspólnie prowadzą działania intensyfikujące rozwijanie e-administracji. Ubieganie się o dotacje unijne

\footnotetext{
${ }^{50}$ Wilk (2014): 173-180.

${ }^{51}$ Osoby starsze maja więcej czasu i preferują kontakt osobisty.

${ }_{52}$ Perdał (2014): 198; Wilk (2014); Tomaszewicz, Buko (2015).

${ }^{53}$ Perdał (2014): 239.

${ }^{54}$ Czubak (2011): 117.
} 
i wprowadzenie cyfryzacji są dla wielu urzędów poważnym wyzwaniem organizacyjno-systemowym, dlatego budowanie współpracy ułatwia ponoszenie kosztów wkładu własnego lub przygotowania wniosku przez firmę zewnętrzną, zwłaszcza w przypadku mniejszych gmin.

Postawę władz wobec podejmowanych działań e-cyfryzacji można scharakteryzować za Perdałem ${ }^{55}$ w następujący sposób: „względnie młody wiek władz gminnych, wyższy poziom wykształcenia oraz wysoki stopień poparcia społecznego i wysoki poziom stabilizacji władz moga wpływać m.in. na poziom świadomości w zakresie potrzeby rozwoju e-administracji. Przesłanka takiego założenia jest występowanie na ogół większej otwartości na innowacje osób młodych i dobrze wykształconych oraz mających duży mandat zaufania do podejmowania trudnych (i często kosztownych) decyzji”. Nie bez znaczenia pozostaje także wiedza i wcześniejsze doświadczenia w pozyskiwaniu środków unijnych na cyfryzację, które to doświadczenia wpływają pozytywnie na dalsze starania o pozyskiwanie dotacji unijnych.

Potencjał instytucji do absorpcji środków w ramach funduszy europejskich warunkowany jest z jednej strony przez zasoby instytucji, z drugiej - przez kapitał wiedzy i doświadczenia związany z tym obszarem ${ }^{56}$. Składają się na niego m.in. zasoby ludzkie, przygotowanie i chęć do starania się o środki unijne, a także w dalszej perspektywie wdrażanie inicjatywy w opisywanym przypadku cyfryzacji. Nie bez znaczenia jest także otwartość na zmiany.

Zaprezentowane czynniki mają charakter potencjalny i są wypadkową dokonanego przeglądu literatury przedmiotu, w dalszej części artykułu zostanie zaprezentowana ich weryfikacja na podstawie wywiadów z urzędnikami gmin.

\section{BADANIE PILOTAŻOWE}

W celu weryfikacji zaprezentowanych w artykule czynników zostało przeprowadzone badanie pilotażowe mające na celu stwierdzenie:

- Które z opisanych czynników mają największe znaczenie dla samorządów ubiegajacych się o dotacje unijne na cyfryzację?

- Czy istnieją inne, nieopisane wcześniej teoretycznie czynniki motywujące gminy do ubiegania się o dotacje?

Pozyskaniu odpowiedzi na powyższe pytania służyło przeprowadzenie siedmiu wywiadów telefonicznych $\mathrm{z}$ urzędnikami wybranych urzędów w województwach: wielkopolskim, zachodniopomorskim, lubuskim i dolnośląskim. Wszystkie urzędy biorace udział w badaniu były/ sa beneficjentami środków unijnych. Wywiady telefoniczne miały różną długość - od 15 do 30 min i zostały przeprowadzone między 1 a 15 grudnia 2018 r. Badanie nie ma charakteru reprezentatywnego, a jedynie przyczynkowy; wskazuje na obszary, które zasługują na dalsze pogłębione badanie.

${ }^{55}$ Perdał (2014): 181.

${ }^{56}$ Bariery w aplikowaniu o środki z EFS przez jednostki samorządu terytorialnego w województwie wielkopolskim, Wojewódzki Urząd Pracy w Poznaniu 2011, <http://www.efs.wup.poznan.pl/att/programy/PO_KL/publikacje/bariery.pdf [dostęp: 22.12.2018]. 
Badani zgodnie przyznali, że najczęstszym czynnikiem wpływającym na podjęcie decyzji o ubieganie się o środki unijne na cyfryzację była współpraca z podmiotami zewnętrznymi. Możemy do nich zaliczyć lokalnych dostawców sprzętu komputerowego i infrastruktury sieciowej, firmy oferujące kompleksową obsługę przygotowywania i obsługi wniosków o dofinansowanie oraz producentów oprogramowania. Otwartość na współpracę i nowe technologie stanowi bardzo ważny czynnik, który sprzyja nie tylko inwestowaniu czasu i wysiłku w przygotowywanie wniosków unijnych, ale także nawiązywaniu współpracy z zewnętrznymi podmiotami. Okazuje się, że większość projektów unijnych to tzw. vendors driven projects ${ }^{57}$, tzn. projekty uruchamiane z inicjatywy producentów oprogramowania, którzy „przychodzą do urzędu z oferta własną oraz ofertą firmy przygotowujacej przetargi.

Z wypowiedzi badanych wynika, że istotną motywacją do starania się o środki unijne jest całkowicie zrozumiała chęć odnowienia istniejacej infrastruktury sprzętowej w urzędzie. Wraz z oprogramowaniem służącym rozwojowi cyfryzacji jednostki moga pozyskać ogromne środki na odnowienie serwerowni i stworzenie nowych stanowisk pracy, co dotychczas nie było uwzględniane w naukowych analizach teoretycznych.

Niezwykle ciekawym zjawiskiem okazał się wynikajacy z konkurencji między gminami tzw. efekt naśladownictwa lub wręcz snobizmu: gdy w sasiedniej gminie projekt już wdrożono, motywowało to daną gminę do starań o uzyskanie finansowania, dlatego że widziała sukces sąsiadów w uzyskaniu dofinansowania z UE.

W zasadzie żadna $\mathrm{z}$ tych przesłanek nie jest podparta formalnymi powodami. Nikt nie dokonuje żadnej analizy własnych potrzeb jako urzędu i potrzeb społeczno-publicznych w gminie. Decydenci w gminach maja znikomy poziom świadomości cyfrowej, nie maja pojęcia, czym są usługi cyfrowe i jakie stwarzają możliwości. Mają bardzo niską wiedzę na temat tego, kiedy usługi cyfrowe należy wdrażać. W większości decyzje o cyfryzacji podejmują lokalni informatycy, którzy poza wiedzą na temat zakupów odpowiedniego sprzętu nie posiadają wiedzy zarządczej w zakresie inwestowania środków w elementy cyfryzacji gminy.

W wypowiedziach badanych nie pojawił się aspekt oczekiwań klienta urzędu, dotyczących wprowadzenia e-administracji, ani też znacznej poprawy sytuacji finansowej urzędu. W wypowiedzi jednego z urzędników pojawił się aspekt dobrych doświadczeń związanych z pozyskaniem dotacji unijnych i było to dla niego zachętą do dalszego działania. Na podstawie przeprowadzonych wywiadów można wstępnie wprowadzić następująca hierarchizację czynników:

1) współpraca z podmiotami zewnętrznymi (7 respondentów),

2) inicjatywa producenta oprogramowania (5 resp.),

3) oferta firmy przygotowujacej przetargi (4 resp.),

4) naśladownictwo innych gmin (4 resp.),

5) dobre doświadczenia związane z pozyskaniem dotacji unijnych (1 resp.).

${ }^{57}$ McIsaac (2008). 
Podsumowując, czynniki wymienione $\mathrm{w}$ wywiadach stanowią jedynie niewielką część spośród czynników wymienionych w literaturze przedmiotu. Można zauważyć, że wprowadzanie zmian w urzędach ma raczej charakter bottom-up niż top-down i wynika raczej z przesłanek wewnętrznych niż czynników zewnętrznych.

\section{PODSUMOWANIE}

Cyfryzacja urzędów to temat bardzo ważny dla polskiej administracji, co wynika nie tylko z zaleceń unijnych, a także rozwijania podobnych systemów $\mathrm{w}$ innych krajach, ale także $\mathrm{z}$ coraz większych potrzeb samych klientów urzędów. Dodatkowo czynnikiem motywującym sa znaczne sumy przeznaczane przez UE na dotowanie projektów poświęconych cyfryzacji. Przeprowadzone badanie pilotażowe wykazało rolę inwestycji w zakup nowoczesnego sprzęt czy oprogramowania dzięki dotacjom unijnym jako pierwszego etapu wprowadzania e-administracji w urzędach. Badanie pokazało także znaczenie dotacji w celu tworzenia nowych miejsc pracy w urzędach związanych bezpośrednio z cyfryzacją lub wdrażaniem e-administracji.

Główną rolę odgrywają jednak czynniki nieformalne skłaniające gminy do ubiegania się o środki unijne (jak na przykład konkurowanie z innymi gminami posiadającymi już środki będące oznaką prestiżu) czy umiejętnego wykorzystania istniejących możliwości. Nie bez znaczenia w ubieganiu się o środki unijne jest kapitał ludzki, z jednej strony określany przez wiedzę o istniejących programach unijnych, z których można pozyskać środki na realizację założonych celów, z drugiej natomiast - dysponujący wcześniejszym doświadczeniem w korzystaniu ze środków unijnych i właściwym ich rozliczaniu.

Decyzje o wnioskowaniu o środki unijne mają według badanych charakter oddolny i związane są z przedsiębiorczym pracownikiem urzędu, głównie informatykiem, który jest świadomy znaczenia wprowadzonych zmian dla rozwoju administracji. Jednocześnie trzeba podkreślić znaczenie przygotowania merytorycznego pracowników urzędu z zakresu samej cyfryzacji i znajomość obsługi nowych rozwiązań technologicznych. Opisane w badaniu czynniki wymagaja z pewnościa głębszej analizy, niemniej ich dokładne zbadanie pozwoli na lepsze wykorzystanie możliwości wynikających z pozyskiwania dotacji unijnych.

Krzysztof Drgas

Wyższa Szkoła Bankowa w Poznaniu

krzysztof.drgas@wsb.poznan.pl

https://orcid.org/0000-0001-7531-6833

Batko, K., Billewicz, G. (2013). E-usługi w biznesie i administracji publicznej. Studia Ekonomiczne 136: 47-63.

Boć, J. (2003). Administracja publiczna jako organizacja inteligentna, [w:] J. Boć (red.), Administracja publiczna. Wrocław: Kolonia Limited: 366-374.

Bogucki, D. (2005). e-Government w Unii Europejskiej. Elektroniczna Administracja 1: 10-15. 
Butkiewicz, M. (2006). Internet w instytucjach publicznych. Zagadnienia prawne. Warszawa: Wydawnictwo Difin.

Centeno, C., Bavel, R. van, Burgelman, J.C. (2005). A prospective view of e-government in the European Union. The Electronic Journal of e-Government 3(2): 59-66.

Czubak, W. (2011). Czynniki determinujące wykorzystanie unijnych środków wsparcia inwestycji w rolnictwie. Zagadnienia Ekonomiki Rolnej nr 4, Instytut Ekonomiki Rolnictwa i Gospodarki Żywnościowej - Państwowy Instytut Badawczy. <http://yadda.icm.edu.pl/yadda/element/ bwmeta1.element.ekon-element-000171192821> [dostęp: 22.12.2018].

Eurostat $(2018)<$ http://ec.europa.eu/eurostat/product?code=isoc_ci_in_h\&language=en\&mode=view > [dostęp: 20.12.2018].

Fleszer, D. (2014). Wokół problematyki e-administracji. Roczniki Administracji i Prawa 14(1): $125-136$.

Gajewski, J. (red.) (2016). Cyfryzacja gospodarki i społeczeństwa - szanse i wyzwania dla sektorów infrastrukturalnych, Instytut Badań nad Gospodarką Rynkową - Gdańska Akademia Bankowa. <https://www.efcongress.com/sites/default/files/publikacja_ekf_2016_cyfryzacja_gospodarki_i_spoeczestwa.pdf> [dostęp: 20.01.2019].

Ganczar, M. (2009). Informatyzacja administracji publicznej. Nowa jakość usług publicznych dla obywateli i przedsiębiorców. Warszawa: CeDeWu.

Grodzka, D. (2007). E-administracja w Polsce, [w:] J. Adamiec (red.), Zagadnienia społeczno-gospodarcze „Infos” nr 18. Warszawa: Wydawnictwo Sejmowe dla Biura Analiz Sejmowych.

Grodzka, D. (2009). E-administracja w Polsce. Studia BAS 3(19): 57-81.

Jeżowski, P. (2002). New Public Management - nowy paradygmat zarządzania w sektorze publicznym, [w:] P. Jeżowski (red.), Zarządzanie w sektorze publicznym - rozwój zrównoważony - metody wyceny. Warszawa: Wydawnictwo SGH: 193-202.

Kickert, W.J.M. (1997). Public Governance in the Netherlands: An Alternative to Anglo-American 'Managerialism'. Public Administration 75(4): 731-752. <http://dx.doi.org/10.1111/14679299.00084>.

Krynicka, H. (2006). Koncepcja nowego zarządzania w sektorze publicznym (New Public Management), Studia Lubuskie 2: 193-202.

Lan, Z., Rosenbloom, D.H. (1992). Public administration in transition? Public Administration Review 52(6): 535-537. <http://dx.doi.org/10.2307/977163>.

Lubińska, T., Strąk, T., Lozano-Platonoff, A., Będzieszak, M., Godek, M. (2007). Budżet zadaniowy w Polsce - istota, struktura, metodyka, [w:] T. Lubińska (red.), Budżet zadaniowy w Polsce. Reorientacja z wydatkowania na zarządzanie pieniędzmi publicznymi. Warszawa: Wydawnictwo Difin: 15-72.

McIsaac, K.A. (2008), Vendors may cost you more than your project: how to avoid vendor risks, Paper presented at PMI ${ }^{\circledR}$ Global Congress - North America, Denver, CO. Newtown Square, PA: Project Management Institute. <https://www.pmi.org/learning/library/vendors-cost-more-project-prevent-risks-6949> [dostęp: 22.12.2018].

Morgan, G. (1999). Obrazy organizacji. Warszawa: Wydawnictwo Naukowe PWN: 17-40.

Ochnio, M. (2012). Nowe Zarządzanie Publiczne (New Public Management) - podstawowe cechy modelu. Jego zastosowanie w Polsce. Warszawa: Stowarzyszenie Instytut Zmian. <http:// iz.org.pl/wp-content/uploads/2012/09/New_Public_Management_Michal_Ochnio_Instytut_ Zmian.pdf>, [dostęp: 9.12.2018].

Perdał, R. (2014). Czynniki rozwoju elektronicznej administracji w samorządzie lokalnym w Polsce. Poznań: Bogucki Wydawnictwo Naukowe.

Pollitt, C. (1990). Managerialism and Public Services. London: Blackwell.

Porębski, L. (2012). Lokalny wymiar elektronicznej demokracji. Kraków: Księgarnia Akademicka.

Program Operacyjny Polska Cyfrowa na lata 2014-2020. <https://www.polskacyfrowa.gov.pl/media/55216/POPC_Program_3_0_17042018.pdf> [dostęp: 16.12.2018].

Prokopowicz, D., Kwasek, A. (2017). Rozwój koncepcji good governance w instytucjach administracji państwowej. Zeszyty Naukowe Uczelni Vistula 55(4): 176-188. <http://yadda.icm.edu. pl/yadda/element/bwmeta1.element.desklight-e5c6b44a-e5a7-48d0-8932-3d55f96473f4> [dostęp: 20.01.2019]. 
Kancelaria Prezesa Rady Ministrów (2009). Raport Polska 2030 wyzwania rozwojowe. <http:// www.wrpo2007-2013.wielkopolskie.pl/zalaczniki1/2012/Raport_Polska_2030_wyzwania_ rozwojowe.pdf> [dostęp: 20.12.2018].

Sakowicz, M. (2007). Modernizacja samorządu terytorialnego w procesie integracji Polski z Unia Europejska. Warszawa: SGH w Warszawie.

Sikora-Gaca, M., Kosowska, U. (red.) (2014). Fundusze europejskie w teorii i praktyce. Warszawa: Wydawnictwo Difin.

Sikora-Gaca M., Piechowicz M., Kleinowski M. (2018). Zarządzanie Funduszami Europejskimi. Warszawa: Wydawnictwo Difin.

Stolarek, I.J. (2017), Zasada dobrego rządzenia w przedsiębiorstwie jest szczególnie istotna. <http:// www.rp.pl/Firma/302179992-Zasada-dobrego-rzadzenia-wprzedsiebiorstwie-jestszczegolnie-istotna.htm> [dostęp: 20.01.2019].

Sześciło, D., Bełdowski, J. (2011). W stronę nowego zarządzania publicznego. <http://nawokandzie.ms. gov.pl/numer-4/opinie-4/w-strone-nowego-zarzadzania-publicznego.html> [dostęp: 9.12.2018].

Szyszka, G., Śliwczyński, B. (red.) (2004). Elektroniczna gospodarka w Polsce. Raport 2003. Poznań.

Śliwiński, M. (2008). Modele biznesowe e-usług. Warszawa: Polska Agencja Rozwoju Przedsiębiorczości.

Tomaszewicz, A., Buko, J. (2015). Determinanty rozwoju e-administracji publicznej w Polsce. Zeszyty Naukowe Uniwersytetu Szczecińskiego 852 - Ekonomiczne Problemy Usług 117: 643-651.

Weber, M. (2004). Racjonalność, władza, odczarowanie. Tłum. M. Holona, Poznań: Wydawnictwo Poznańskie.

Weerakkody, V., El-Haddadeh, R., Sabol, T., Ghoneim, A., Dzupka, P. (2012). E-government implementation strategies in developed and transition economies: a comparative study. International Journal of Information Management 32(1): 66-74. <https://doi.org/10.1016/j.ijinfomgt.2011.10.005>.

Wilk, S. (2014). E-administracja w społeczeństwie informacyjnym. Model a rzeczywistość na przykładzie województwa podkarpackiego. Rzeszów: Wydawnictwo Uniwersytetu Rzeszowskiego.

Zawicki, M. (2002). New Public Management i Public Governance - zarys koncepcji zarządzania publicznego, [w:] J. Hauser (red.), M. Kukiełka, Studia z zakresu zarządzania publicznego. Tom 2. Kraków: Wydawnictwo AE: 72-89.

\section{EU FUNDED DIGITIZATION OF LOCAL GOVERNMENT AND ITS RATIONALE}

Sum mary

The subject of this article is the factors influencing the acquisition of EU subsidies for the purpose of digitizing local government units. The theoretical part describes the issues underlying the digitization process, which is associated with a new approach to the office-client relationship as well as data collection and data management. In the empirical part, the premises for the digitization of local government units financed from EU funds are reviewed and verified on the basis of a pilot study consisting of telephone interviews with staff employed in selected offices. Apart from formal reasons, such as the municipal budget or previous experience in obtaining EU funds, informal reasons also turned out to be important, such as the introduction of a project in a neighbouring municipality.

Keywords: digitization; e-services; EU funds; formal premises 